Revista Perspectivas Online: Exatas \& Engenharias Anais do V Seminário P\&D PROVIC/PIBIC II Encontro de Iniciação Científica CNPq Vol. 10, n 29, Suplemento, 2020

\title{
Projeto de uma aeronave radiocontrolada nos requisitos da competição SAE aerodesign com validação através de análises estruturais e aerodinâmica
}

\author{
Deryck Machado Rangel ${ }^{1}$, Cláudia Márcia Ribeiro Machado Albernaz ${ }^{2}$ \\ (1) Aluno de Iniciação Científica do PIBIC/ISECENSA - Curso de Engenharia Mecânica; (2) Pesquisadora Orientadora - Laboratório de Análise e \\ Projeto de Sistemas Mecânicos - LAPSIM/ISECENSA, Rua Salvador Correa, 139, Centro, Campos dos Goytacazes, RJ, Brasil.
}

A construção de aviões em escala reduzida possui grande crescimento tecnológico atualmente, devido à possibilidade de testar e melhorar diferentes aspectos a um baixo custo com grande flexibilidade de alterações e velocidade de aplicação. Competições como a promovida pela SAE Aerodesign possibilitam inovações e melhorias de projetos possuindo caráter multidisciplinar com tarefas de design, manufatura, planejamento, simulação e modelagem computacional, além da utilização de conceitos de qualidade, gerenciamento de projetos envolvendo também alunos de outras engenharias exercitando a capacidade empreendedora e adquirindo novos conhecimentos. O presente trabalho tem como objetivo desenvolver e projetar uma aeronave que respeite os requisitos definidos pelo regulamento da competição SAE Brasil Aerodesign, com validação através de análises estruturais e aerodinâmicas. Sendo assim, após uma vasta pesquisa de teorias, métodos, regulamentos e bechmarking serão elaborados os projetos conceitual, preliminar e detalhado da aeronave. Por meio deste trabalho pretende-se elaborar e validar um projeto de uma aeronave radiocontrolada que atenda os requisitos da competição SAE Aerodesign para que posteriormente seja construído um protótipo, dando início a primeira equipe de competição no ISECENSA.

Palavras-chave: Aeronave, Aerodesign, Análise Estrutural.

Instituição de Fomento: ISECENSA; CNPq. 